\title{
ANALISIS PENGARUH KEPERCAYAAN, KEAMANAN, KUALITAS PELAYANAN, KUALITAS PRODUK, DAN PERSEPSI RISIKO TERHADAP KEPUTUSAN PEMBELIAN MELALUI SITUS JEJARING SOSIAL (STUDI KASUS PADA MAHASISWA DI KOTA PADANG)
}

\author{
Genny Intan Sari $\mathrm{HR}^{1)}$, Riche Fermayani ${ }^{2)}$, Romi Rianto Harahap ${ }^{3)}$ \\ gennyhrx2@gmail.com ${ }^{1)}$, richefermayani@gmail.com ${ }^{2)}$, romi.rianto.harahap@gmail.com ${ }^{3)}$ \\ STIE Perbankan Indonesia
}

\begin{abstract}
This study aims to look at the analysis of the influence of trust, security, service quality, product quality, and risk perception on purchasing decisions through social networking sites (case studies on students in the city of Padang). The sample in this study was measured by distributing questionnaires to 100 students in the city of Padang so that there were 100 research samples. Based on the partial t test it can be concluded that trust has a positive and significant influence on purchasing decisions because the significance value obtained is 0,000 $<0,05$, security has a positive and significant influence on purchasing decisions because the significance value obtained is $0.001<0.05$, service quality has a negative and significant effect on purchasing decisions because the significance value obtained is $0.033<0.05$, product quality has a positive and significant influence on purchasing decisions because the significance value obtained is $0.008<0.05$, perception of risk has a positive and significant effect on purchasing decisions because the significance value obtained is $0.002<0.05$, The ability of independent variables in this case is trust, security, service quality, product quality, and risk perception of the dependent variable in this case is a purchasing decision of $87.7 \%$ while the remaining $12.3 \%$ is influenced by other variables other than variables that are not included in the research model.
\end{abstract}

Keyword: Trust, Security, Service Quality, Product Quality, Risk Perception, and PurchasingDecision

\begin{abstract}
Abstrak : Penelitian ini bertujuan untuk melihat analisis pengaruh kepercayaan, keamanan, kualitas pelayanan, kualitas produk, dan persepsi risiko terhadap keputusan pembelian melalui situs jejaring sosial (studi kasus pada mahasiswa di Kota Padang). Sampel dalam penelitian ini diukur dari penyebaran kuesioner kepada 100 orang mahasiswa di Kota Padang sehingga terdapat 100 sampel penelitian. Berdasarkan uji t parsial dapat disimpulkan bahwa kepercayaan memiliki pengaruh positif dan signifikan terhadap keputusan pembelian karena nilai signifikansi yang diperoleh sebesar $0,000<0,05$, keamanan memiliki pengaruh positif dan signifikan terhadap keputusan pembelian karena nilai signifikansi yang diperoleh sebesar 0,001 <0,05, kualitas pelayanan memiliki pengaruh negatif dan signifikan terhadap keputusan pembelian karena nilai signifikansi yang diperoleh sebesar $0,033<0,05$, kualitas produk memiliki pengaruh positif dan signifikan terhadap keputusan pembelian karena nilai signifikansi yang diperoleh sebesar $0,008<0,05$, persepsi resiko memiliki pengaruh positif dan signifikan terhadap keputusan pembelian karena nilai signifikansi yang diperoleh sebesar 0,002<0,05. Kemampuan variabel independen dalam hal ini adalah kepercayaan, keamanan, kualitas pelayanan, kualitas produk, dan persepsi resiko terhadap variabel dependennya dalam hal ini adalah keputusan pembelian sebesar $87,7 \%$ sedangkan sisanya sebesar 12,3\% dipengaruhi oleh variabel lain selain dari variabel yang tidak dimasukkan ke dalam model penelitian.
\end{abstract}

Keyword : Kepercayaan, Keamanan, Kualitas Pelayanan, Kualitas Produk, Persepsi Resiko, dan Keputusan Pembelian 


\section{A. PENDAhUluan}

Eletronic commerce (e-commerce) merupakan implementasi dari teknologi yang bisa digunakan untuk peningkatan bisnis, penjualan dan pembelian. "E-commerce merupakan suatu saluran online yang dapat dijangkau oleh seseorang melalui konsumer, yang digunakan oleh pelaku bisnis dalam melakukan aktivitas bisnisnya dan dapat digunakan oleh konsumen untuk mendapatkan informasi dengan menggunakan bantuan komputer yang dalam prosesnya diawali dengan memberi jasa informasi pada konsumen dalam penentuan pilihan" (Kotler \& Amstrong, 2012). Menurut The Nielsen Global Survey Of E-Commerce (2014), yaitu survey yang pernah dilakukan mengenai kebiasaan berbelanja online, dimana hasilnya menunjukkan bahwa masyarakat Indonesia begitu nyaman dalam melakukan belanja online via internet. Dengan demikian dapat kita ketahui bahwa tidak mengherankan jika pembelian barang-barang fashion yang dilakukan secara online menjadi hal yang biasa seperti berkunjung ke toko-toko atau pusat perbelanjaan.

Pengguna internet di Indonesia terus-menerus mengalami peningkatan dari tahun ke tahun. Sebagai contoh pada tahun 2010 hanya sebanyak 42 juta pengguna, tetapi jika dibandingkan dengan tahun 2017 maka dapat dilihat terjadi kenaikan sebanyak 3x lipat dalam kurun waktu 7 tahun. Kemudian apabila dilihat berdasarkan usia, maka pengguna terbanyak berada pada rentang usia 19-34 tahun yaitu sebanyak 49,52\% atau sekitar 70,94 juta pengguna internet. Berdasarkan data APJII di atas dapat dilihat bahwa pengguna internet di Indonesia didominasi oleh generasi millenial yang memang sudah melek internet. Generasi millenial atau kadang disebut juga sebagai generasi Y adalah sekelompok orang yang lahir setelah generasi $\mathrm{X}$, yaitu pada kisaran tahun 1980-2000, (Yovirizka dan Wahjoedi, 2018).

Dalam penelitian ini yang menjadi alasan peneliti memilih melibatkan mahasiswa sebagai respondennya adalah dengan pertimbangan bahwa mahasiswa telah melalui masa pendidikan yang cukup lama dan pengetahuan yang diperoleh cukup memadai. Baik itu pendidikan formal maupun pendidikan informal yang didapat di lingkungan keluarga dan masyarakat. Mahasiswa yang akan dijadikan responden adalah mahasiswa yang berasal dari Perguruan Tinggi di Kota Padang, baik itu Perguruan Tinggi Negeri dan Perguruan Tinggi Swasta. http://www.forlap.ristekdikti.go.id (2019)

Menurut Felicitas (2012) terdapat beberapa alasan mengapa orang-orang memiliki niat untuk melakukan belanja online. Selain karena adanya faktor kebutuhan, alasan ini juga menjadi faktor pendorong bagi seorang konsumen untuk melakukan belanja secara online. Alasan yang pertama adalah agar dapat menghemat waktu dan biaya. Dengan adanya belanja online, konsumen cukup hanya dengan memainkan jari telunjuk diatas smartphone mereka untuk dapat berpindah dari satu toko ke toko online lainnya. Ke dua, online shop akan selalu melakukan perbaikan diri, karena mereka selalu dapat menerima masukan dari konsumen secara langsung pada kolom komentar yang tersedia, baik itu mengenai hal-hal yang perlu diperbaiki, dapat diperbaiki atau dapat meningkatkan kelebihan yang dimiliki agar dapat lebih memuaskan konsumen saat berbelanja. Ke tiga, pada online shop pelanggan dapat membaca langsung testimoni dari pelanggan lain yang sudah pernah melakukan pembelian atau mendapatkan pelayanan dari online shop tersebut. Ke empat, pihak online shop juga akan memberikan rekomendasi mengenai barang-barang lain yang mungkin berkaitan dengan barang yang sedang dicari konsumen. Ke lima, para pelanggan online shop tidak perlu berdesakkan dengan pelanggan lain atau merasa bising dengan hal-hal yang mengganggu.

Menurut Kotler dan Keller (2012), "kepercayaan adalah suatu kesediaan perusahaan untuk bergantung pada mitra bisnisnya. Kepercayaan bergantung pada beberapa faktor antar pribadi dan antar organisasi seperti kompetensi, kejujuran, integritas dan kebaikan hati". Kepercayaan merupakan pondasi utama yang sangat penting dalam menjalankan sebuah bisnis. Kepercayaan adalah hal pertama yang harus dibangun oleh para pelaku bisnis. Hal ini juga akan menjadi penentu bagi keberhasilan dari suatu bisnis, karena ketika seseorang mulai melakukan transaksi secara online maka hal utama yang akan diperhatikannya adalah apakah toko online tersebut dapat dipercaya atau tidak. Menurut Kotler dan Keller (2016:225) ada beberapa indikator kepercayaan konsumen, yaitu sebagai berikut: 
a. Benevolence (kesungguhan/ketulusan).

b. Ability (kemampuan).

c. Integrity (integritas).

d. Willingness to depend.

Park dan Kim (2006) dalam Sukma (2012) mengatakan, "keamanan sebagai kemampuan online shop dalam melakukan pengontrolan dan penjagaan serta keamanan atas transaksi data konsumen". Kemudian Park dan Kim (2006) dalam Sukma, (2012) menambahkan bahwa "jaminan keamanan sangat berperan penting dalam pembentukan kepercayaan dengan mengurangi kekhawatiran konsumen tentang penyalahgunaan data pribadi dan transaksi data yang mudah rusak". Artinya keamanan dan kepercayaan memiliki hubungan yang saling mempengaruhi satu sama lain. Jaminan keamanan menjadi pendorong bagi konsumen untuk lebih percaya dan merasa nyaman pada online shop yang mereka pilih. Berikut adalah indikatorindikator keamanan menurut Hariyanti (2012) meliputi:

a. Terjaminnya transaksi.

b. Kemudahan trasnsaksi melalui COD (Cash On Delivery) ataupun transfer.

c. Adanya bukti transaksi melalui resi pengiriman.

d. Citra Penjual online.

e. Kualitas produk.

Kotler (2016) mengatakan, "kualitas pelayanan merupakan setiap tindakan atau kegiatan yang ditawarkan oleh salah satu pihak kepada pihak lainnya, yang pada dasarnya tidak berwujud dan tidak mengakibatkan perpindahan kepemilikan apapun". Kualitas pelayanan yang diberikan hendaknya mampu memberikan kenyamanan bagi konsumen dalam berbelanja serta mampu membuat konsumen merasa diperhatikan sehingga konsumen menjadi lebih loyal pada online shop tersebut. Berikut ini adalah lima dimensi karakteristik kualitas pelayanan:

a. Reliability (kehandalan).

b. Responsiveness (ketanggapan).

c. Assurance (jaminan).

d. Empathy (empati).

e. Tangibles (bukti langsung).

Kotler dan Keller (2016:164) mendefinisikan, "kualitas produk merupakan kemampuan yang dimiliki suatu barang untuk memberikan hasil atau kinerja yang sesuai bahkan melebihi apa yang diharapkan seorang konsumen". Baik atau buruknya kualitas dari suatu produk akan menjadi faktor penentu bagi konsumen dalam melakukan keputusan pembelian. Berikut adalah dimensi dan indikator kualitas produk menurut David Garvin dalam buku Fandy Tjiptono (2016:134) yaitu:

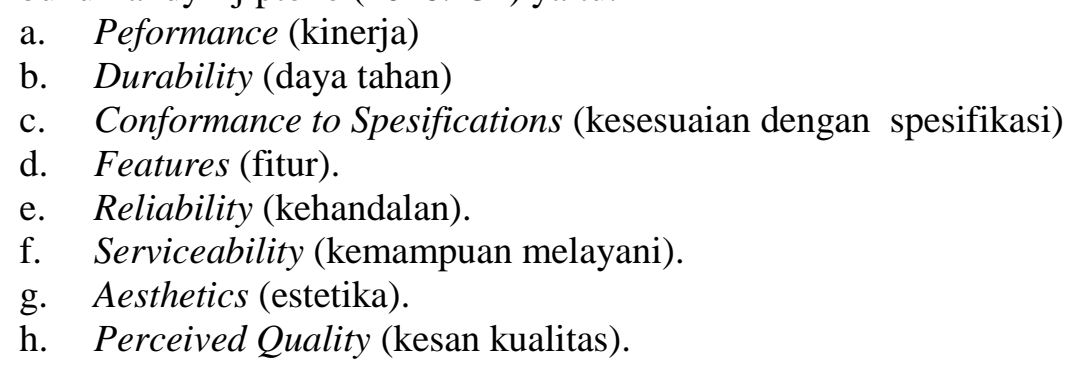

Sciffman dan Kamuk (2010) dalam Rosalia, D.dan Ellyawati (2016) mendefinisikan, "persepsi risiko adalah ketidakpastian yang dihadapi oleh konsumen ketika mereka tidak dapat meramalkan dampak dari keputusan pembelian yang mereka lakukan". Persepsi risiko juga dapat diartikan sebagai penilaian subjektif oleh seseorang terhadap kemungkinan dari sebuah kejadian dan seberapa khawatirnya seseorang dengan konsekuensi atau dampak yang ditimbulkan oleh kejadian tersebut. Semakin kecil persepsi risiko yang mungkin akan dihadapi konsumen maka semakin besar keinginan konsumen untuk dapat melakukan pembelian terhadap suatu produk. Menurut Masoud (2013) dalam jual beli pada online shop, ada enam macam risiko yang mungkin terjadi yaitu: 

a. Risiko finansial.
b. Risiko produk.
c. Risiko waktu.
d. Risiko pengiriman.
e. Risiko sosial.
f. Risiko keamanan.

Kotler dan Amstrong (2012:128) mengatakan bahwa, "Costumer buyer behavior refers to the buying behavior of final costumers-individuals and households who buy goods and services for personal consumption". Menurut Kotler dan Keller yang dialih bahasakan oleh Fandy Tjiptono (2012:184) menjelaskan bahwa keputusan konsumen melakukan pembelian suatu produk/jasa meliputi hal berikut:
a. Pilihan produk
b. Pilihan merek
c. Pilihan penyalur
d. Waktu pembelian
e. Jumlah pembelian

Untuk lebih jelasnya kerangka penelitian ini digambarkan pada gambar 1 berikut:

\section{Ganbar 1. Kerangka Penelitian}

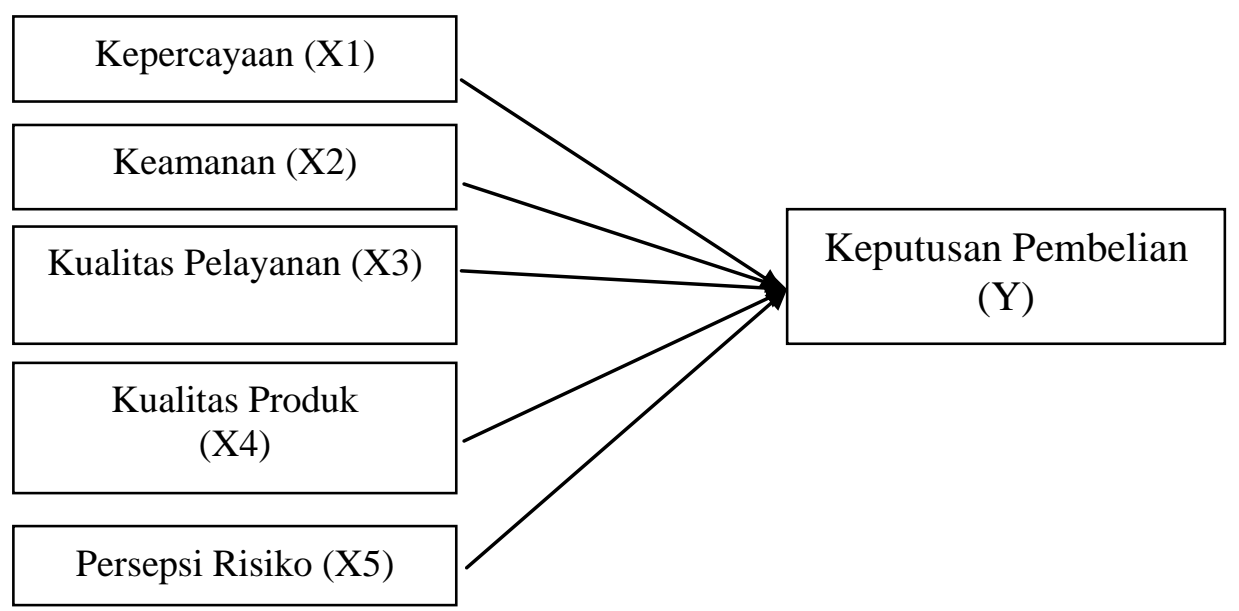

\section{Sumber: Kotler dan Keller (2012)}

Berdasarkan kerangka penelitian yang telah disajikan tersebut teori-teori pendukung yang telah dipaparkan sebelumnya maka penulis merumuskan 2 hipotesis dalam penelitian ini yaitu:

H1: Diduga kepercayaan berpengaruh signifikan terhadap keputusan pembelian konsumen melalui situs jejaring sosial.

H2: Diduga keamanan berpengaruh signifikan terhadap keputusan pembelian konsumen melalui situs jejaring sosial.

H3: Diduga kualitas pelayanan berpengaruh signifikan terhadap keputusan pembelian konsumen melalui situs jejaring sosial.

H4: Diduga kualitas produk berpengaruh signifikan terhadap keputusan pembelian konsumen melalui situs jejaring sosial.

H5: Diduga persepsi risiko berpengaruh signifikan terhadap keputusan pembelian konsumen melalui situs jejaring sosial. 


\section{B. METODOLIGI PENELITIAN}

Untuk dapat melakukan pengujian kebenaran terhadap hipotesis yang dikemukakan sebelumnya, maka jenis dan sumber data yang digunakan dalam penelitian ini adalah data kuantitatif dan sumber data primer yang melakukan penelitian langsung kepada mahasiswa/mahasiswi yang melakukan belanja secara online. Populasi dalam penelitian ini adalah seluruh mahasiswa dan mahasiswi dari Perguruan Tinggi yang ada di Kota Padang yang berjumlah 154.863 orang. http://www.forlap.ristekdikti.go.id (2019)

Metode penentuan sampel yang digunakan dalam penelitian ini adalah accidental sampling, dimana teknik penentuan sampel yang berdasarkan pada kebetulan, yaitu siapa saja yang secara kebetulan bertemu dengan peneliti dan dapat digunakan sebagai sampel, bila dipandang orang tersebut cocok sebagai sumber data (Sugiyono, 2016:60). Dalam penelitian ini yang menjadi sampel adalah seluruh mahasiswa dan mahasiswi Perguruan Tinggi di Kota Padang yang pernah melakukan belanja secara online melalui situs jejaring sosial berjumlah 100 orang yang didapat dengan menggunakan rumus Slovin.

Sebelum melakukan analisis regresi, perlu dilakukan pengujian analisis data terlebih dahulu, agar data sampel yang diolah benar-benar dapat mewakili populasi secara keseluruhan. Adapun uji asumsi klasik yang digunakan sebagai berikut:

\section{Uji Normalitas}

Uji normalitas data dilakukan bertujuan untuk menguji apakah dalam model regresi, variabel dependen atau independen mempunyai distribusi secara normal atau tidak. Sugiyono, (2015) mengatakan, "bila data terdistribusi normal maka teknik statistik yang akan digunakan adalah statistik parametriks". Dalam penelitian ini cara yang digunakan yaitu uji KolmogorovSmirnov (uji K-S). Apabila nilai probabilitas signifikansi kurang dari nilai $\alpha=0,05$ maka data tidak terdistribusi secara normal. Apabila nilai probabilitas signifikansi lebih dari $\alpha=0,05$ maka data terdistribusi secara normal.

\section{Uji Multikolinearitas}

Uji Multikolinieritas adalah uji yang dilakukan untuk menguji adanya korelasi antar variabel indpenden. Pada model regresi yang baik seharusnya tidak terjadi korelasi antara variabel independen. Jika variabel independen saling berkorelasi, maka variabel tersebut dikatakan tidak ortogonal. Variabel ortogonal adalah variabel indpenden sama dengan nol. Untuk dapat mendeteksi ada atau tidaknya multikolinieritas yang terdapat dalam model regresi adalah dengan cara melihat nilai variance inflation factor (VIF). Apabila nilai VIF lebih besar dari 10, maka dalam hal ini terjadi multikolinieritas data (Ghozali, 2016).

\section{Uji Heteroskedastisitas}

Adalah uji yang digunakan untuk melihat apakah dalam model regresi terjadi ketidaksamaan variance dari residual satu pengamatan ke pengamatan lain. Jika variance dari residual satu pengamatan ke pengamatan lain adalah tetap, maka disebut homoskedastisitas. Uji heteroskedastisitas dilakukan dengan cara melihat grafik plot antara nilai prediksi pada variabel bebas yaitu ZPRED dengan residualnya SRESID. Deteksi ini dilakukan dengan melihat ada tidaknya pola tertentu pada grafik scatterplot antara SRESID dan ZPRED dimana sumbu Y adalah $\mathrm{Y}$ yang telah diprediksi dan sumbu $\mathrm{X}$ adalah residual (Y prediksi-Y sesungguhnya) yang telah di studenized (Ghozali, 2016).

Sedangkan untuk pengujian hipotesis akan dimulai dari persamaan regresi dan dilanjutkan dengan uji lainnya. Dengan rincian sebagai berikut:

\section{Analisis Regresi Berganda}

Metode yang digunakan untuk melihat pengaruh kepercayaan, keamanan, kualitas pelayanan, kualitas produk dan persepsi risiko terhadap keputusan pembelian melalui situs jejaring sosial pada mahasiswa di Kota Padang adalah uji regresi berganda. Rumus yang digunakan sebagai berikut:

$$
\begin{array}{cl}
\mathrm{Y}=\mathrm{b}_{1} \mathrm{X}_{1}+\mathrm{b}_{2} \mathrm{X}_{2}+\mathrm{b}_{3} \mathrm{X}_{3}+\mathrm{b}_{4} \mathrm{X}_{4}+\mathrm{b}_{5} \mathrm{X}_{5}+\mathrm{e} \\
\text { Keterangan: } & \mathrm{Y}=\text { keputusan pembelian online } \\
& \mathrm{X}_{1}=\text { kepercayaan }
\end{array}
$$




\section{Uji t Parsial}

$$
\begin{aligned}
& \mathrm{X}_{2}=\text { keamanan } \\
& \mathrm{X}_{3}=\text { kualitas pelayanan } \\
& \mathrm{X}_{4}=\text { kualitas produk } \\
& \mathrm{X}_{4}=\text { persepsi risiko }
\end{aligned}
$$

Uji t dilakukan untuk menguji pengaruh variabel bebas satu persatu (parsial) terhadap variabel terikat (Y). Kriteria pengujian "jika nilai significant<level of significant (alpha) maka menunjukkan ada signifikansi pengaruh antara variabel bebas secara parsial terhadap variabel terikatnya".

\section{Uji f Simultan}

Uji f-simultan digunakan untuk melihat tingkat signifikansi pengaruh antara variabel bebas dengan variabel terikat secara simultan (bersamaan). Kriteria pengujian "jika nilai significant<level of significant (alpha) maka menunjukkan ada signifikansi pengaruh antara variabel bebas secara parsial terhadap variabel terikatnya".

\section{Koefisien Determinasi (Adj. $\mathbf{R}^{2}$ )}

Koefisien determinasi digunakan untuk menjelaskan proporsi variabel terikat yang mampu dijelaskan oleh variasi variabel bebasnya. Nilai koefisien determinasi adalah $0<\mathrm{R}^{2}<1$. Apabila nilai $\mathrm{R}^{2}$ kecil maka berarti kemampuan variabel bebas dalam menjalankan variabel terikat sangat terbatas. Nilai yang mendekati satu berarti variabel-variabel independen mampu memberikan hampir semua informasi yang dibutuhkan untuk memprediksi variasi variabel dependen. Nilai adjusted $\mathrm{R}^{2}$ dapat bernilai negatif, walaupun nilai yang dikehendaki harus bernilai positif.

\section{PEMBAHASAN}

Hasil Uji Asumsi Klasik

1. Uji Normalitas Data

Hasil uji normalitas data adalah :

Tabel 1. Hasil Uji Normalitas Data

One-Sample Kolmogorov-Smirnov Test

\begin{tabular}{|ll|r|r|r|r|r|r|}
\hline & & $\begin{array}{c}\text { Keputusan } \\
\text { Pembelian }\end{array}$ & Kepercayaan & Keamanan & $\begin{array}{c}\text { Kualitas } \\
\text { Pelayanan }\end{array}$ & $\begin{array}{c}\text { Kualitas } \\
\text { Produk }\end{array}$ & $\begin{array}{c}\text { Persepsi } \\
\text { Resiko }\end{array}$ \\
\hline $\mathrm{N}$ & 100 & 100 & 100 & 100 & 100 & 100 \\
Normal & Mean & 18.7000 & 18.5400 & 17.2900 & 17.2900 & 28.8000 & 22.0200 \\
Parameters & Std. & 4.50028 & 4.22695 & 4.96919 & 5.22290 & 8.09664 & 5.84649 \\
$\mathrm{~b}$ & Deviation & .085 & .084 & .086 & .086 & .087 & .087 \\
Most & Absolute & .082 & .063 & .086 & .086 & .087 & .086 \\
Extreme & Positive & -.085 & -.084 & -.082 & -.084 & -.077 & -.087 \\
Differences & Negative & .085 & .084 & .086 & .086 & .087 & .087 \\
Test Statistic & & $.070^{\mathrm{c}}$ & $.076^{\mathrm{c}}$ & $.065^{\mathrm{c}}$ & $.067^{\mathrm{c}}$ & $.060^{\mathrm{c}}$ & $.062^{\mathrm{c}}$ \\
\hline
\end{tabular}

a. Test distribution is Normal.

b. Calculated from data.

c. Lilliefors Significance Correction.

Sumber : Hasil Pengolahan, 2019

Berdasarkan tabel 1 di atas dapat dijelaskan bahwa nilai asymp. sig untuk variabel keputusan pembelian adalah sebesar 0,070 >0,05 maka data sudah terdistribusi normal. Nilai asymp. sig untuk variabel kepercayaan adalah sebesar 0,076>0,05 maka data sudah terdistribusi normal. Nilai asymp. sig untuk variabel keamanan adalah sebesar 0,065>0,05 maka data sudah terdistribusi normal. Nilai asymp. sig untuk variabel kualitas pelayanan adalah sebesar 0,067>0,05 maka data sudah terdistribusi normal. Nilai asymp. sig untuk variabel kualitas produk adalah sebesar 0,060 >0,05 maka data sudah terdistribusi normal. Nilai asymp. 
sig untuk variabel persepsi resiko adalah sebesar 0,062 > 0,05 maka data sudah terdistribusi normal.

\section{Uji Multikolinearitas}

Hasil uji multikolinearitas dalam penelitian ini adalah :

Tabel 2. Hasil Uji Multikolinearitas Data Coefficients $^{\mathrm{a}}$

\begin{tabular}{|c|c|c|c|}
\hline \multirow{2}{*}{\multicolumn{2}{|c|}{ Model }} & \multicolumn{2}{|c|}{ Collinearity Statistics } \\
\hline & & Tolerance & VIF \\
\hline \multirow[t]{6}{*}{1} & (Constant) & & \\
\hline & Kepercayaan & .215 & 4.654 \\
\hline & Keamanan & .189 & 5.302 \\
\hline & Kualitas Pelayanan & .253 & 3.960 \\
\hline & Kualitas Produk & .159 & 6.280 \\
\hline & Persepsi Resiko & .160 & 6.238 \\
\hline
\end{tabular}

a. Dependent Variable: Keputusan Pembelian

Sumber : Hasil Pengolahan, 2019

Berdasarkan tabel 2 di atas dapat dijelaskan bahwa nilai VIF untuk variabel kepercayaan adalah sebesar 4,654 $<10$ dan tolerance sebesar $0,215>0,1$ maka data tidak terjadi multikolinearitas. Nilai VIF untuk variabel keamanan sebesar 5,302 $<10$ dan tolerance sebesar 0,189>0,1 maka tidak terjadi multikolinearitas. Nilai VIF untuk variabel kualitas pelayanan sebesar 3,960 < 10 dan tolerance sebesar $0,253>0,1$ maka tidak terjadi multikolinearitas. Nilai VIF untuk variabel kualitas produk sebesar 6,280 < 10 dan tolerance sebesar 0,159>0,1 maka tidak terjadi multikolinearitas. Nilai VIF untuk variabel persepsi resiko sebesar $6,238<10$ dan tolerance sebesar $0,160>0,1$ maka tidak terjadi multikolinearitas.

\section{Uji Heteroskedastisitas}

Hasil uji heteroskedastisitas dalam penelitian ini adalah :

\section{Gambar 2. Hasil Uji Heteroskedastisitas}

$$
\text { Scatterplot }
$$

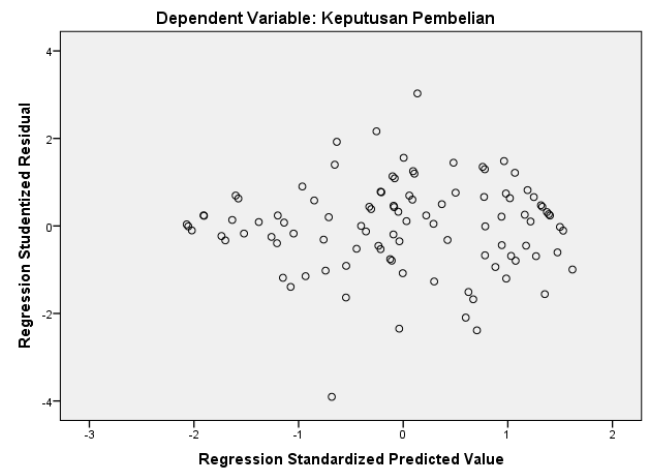

Sumber : Hasil Pengolahan, 2019

Berdasarkan gambar 2 di atas dapat dijelaskan bahwa plot atau titik menyebar secara tidak beraturan dan tidak membentuk pola tertentu maka data terbebas dari gejala heteroskedastisitas. Artinya data dalam penelitian ini tidak terjadi gejala heteroskedastisitas sehingga dapat dipergunakan untuk pengujian statistik selanjutnya.

\section{Hasil Pengujian Hipotesis \\ 1. Uji Regresi Linear Berganda}


Hasil uji regresi linear berganda pada penelitian ini adalah :

Tabel 3. Hasil Uji Regresi Linear Berganda Coefficients

\begin{tabular}{|c|c|c|c|c|c|c|}
\hline \multirow{2}{*}{\multicolumn{2}{|c|}{ Model }} & \multicolumn{2}{|c|}{ Unstandardized Coefficients } & \multirow{2}{*}{$\begin{array}{c}\begin{array}{c}\text { Standardized } \\
\text { Coefficients }\end{array} \\
\text { Beta }\end{array}$} & \multirow[b]{2}{*}{$\mathrm{t}$} & \multirow[b]{2}{*}{ Sig. } \\
\hline & & $\mathrm{B}$ & Std. Error & & & \\
\hline \multirow[t]{6}{*}{1} & (Constant) & 1.370 & .719 & & 1.906 & .060 \\
\hline & Kepercayaan & .372 & .081 & .350 & 4.589 & .000 \\
\hline & Keamanan & .242 & .074 & .268 & 3.292 & .001 \\
\hline & Kualitas Pelayanan & -.131 & .061 & -.152 & -2.160 & .033 \\
\hline & Kualitas Produk & .133 & .049 & .240 & 2.713 & .008 \\
\hline & Persepsi Resiko & .212 & .068 & .275 & 3.116 & .002 \\
\hline
\end{tabular}

a. Dependent Variable: Keputusan Pembelian

Sumber : Hasil Pengolahan, 2019

Berdasarkan tabel 3 di atas dapat dibentuk persamaan regresi untuk variabel penelitian yaitu :

$$
\mathrm{Y}=1,370+0,372 \mathrm{X}_{1}+0,242 \mathrm{X}_{2}-0,131 \mathrm{X}_{3}+0,133 \mathrm{X}_{4}+0,212 \mathrm{X}_{5}+\mathrm{e}
$$

Hasil persamaan regresi di atas dapat diinterpretasikan ke dalam beberapa penjelasan berikut ini yaitu :

1. Nilai konstanta pada penelitian ini adalah sebesar 1,370 dengan tanda positif. Artinya jika kepercayaan, keamanan, kualitas pelayanan, kualitas produk, dan persepsi resiko bernilai nol atau tetap maka keputusan pembelian akan mengalami peningkatan sebesar 1,370 satuan.

2. Nilai koefisien regresi dari variabel kepercayaan adalah sebesar 0,372 dengan tanda positif. Artinya kepercayaan memiliki hubungan searah dengan keputusan pembelian dimana setiap peningkatan satu satuan kepercayaan maka akan mampu meningkatkan keputusan pembelian sebesar 0,372 satuan. Begitu juga sebaliknya jika terjadi penurunan.

3. Nilai koefisien regresi dari variabel keamanan adalah sebesar 0,242 dengan tanda positif. Artinya keamanan memiliki hubungan searah dengan keputusan pembelian dimana setiap peningkatan satu satuan keamanan maka akan mampu meningkatkan keputusan pembelian sebesar 0,242 satuan. Begitu juga sebaliknya jika terjadi penurunan.

4. Nilai koefisien regresi dari variabel kualitas pelayanan adalah sebesar 0,131 dengan tanda negatif. Artinya kualitas pelayanan memiliki hubungan berlawanan arah dengan keputusan pembelian dimana setiap peningkatan satu satuan kualitas pelayanan maka akan mampu menurunkan keputusan pembelian sebesar 0,131 satuan. Begitu juga sebaliknya jika terjadi penurunan.

5. Nilai koefisien regresi dari variabel kualitas produk adalah sebesar 0,133 dengan tanda positif. Artinya kualitas produk memiliki hubungan searah dengan keputusan pembelian dimana setiap peningkatan satu satuan kualitas produk maka akan mampu meningkatkan keputusan pembelian sebesar 0,133 satuan. Begitu juga sebaliknya jika terjadi penurunan.

6. Nilai koefisien regresi dari variabel persepsi resiko adalah sebesar 0,212 dengan tanda positif. Artinya persepsi resiko memiliki hubungan searah dengan keputusan pembelian dimana setiap peningkatan satu satuan persepsi resiko maka akan mampu meningkatkan keputusan pembelian sebesar 0,212 satuan. Begitu juga sebaliknya jika terjadi penurunan.

\section{Uji t Parsial}

Hasil uji t parsial dalam penelitian ini adalah : 
Tabel 4. Hasil Uji t Parsial Coefficients $^{\mathrm{a}}$

\begin{tabular}{|c|c|c|c|c|c|c|}
\hline \multirow{2}{*}{\multicolumn{2}{|c|}{ Model }} & \multicolumn{2}{|c|}{ Unstandardized Coefficients } & \multirow{2}{*}{$\begin{array}{c}\begin{array}{c}\text { Standardized } \\
\text { Coefficients }\end{array} \\
\text { Beta }\end{array}$} & \multirow[b]{2}{*}{$\mathrm{t}$} & \multirow[b]{2}{*}{ Sig. } \\
\hline & & $\mathrm{B}$ & Std. Error & & & \\
\hline \multirow[t]{6}{*}{1} & (Constant) & 1.370 & .719 & & 1.906 & .060 \\
\hline & Kepercayaan & .372 & .081 & .350 & 4.589 & .000 \\
\hline & Keamanan & .242 & .074 & .268 & 3.292 & .001 \\
\hline & Kualitas Pelayanan & -.131 & .061 & -.152 & -2.160 & .033 \\
\hline & Kualitas Produk & .133 & .049 & .240 & 2.713 & .008 \\
\hline & Persepsi Resiko & .212 & .068 & .275 & 3.116 & .002 \\
\hline
\end{tabular}

a. Dependent Variable: Keputusan Pembelian

Sumber : Hasil Pengolahan, 2019

Berdasarkan tabel 4 di atas dapat dijelaskan bahwa nilai signifikansi untuk variabel kepercayaan adalah sebesar $0,000<0,05$ yang didukung oleh nilai t hitung sebesar 4,589 >t tabel sebesar 1,983 maka dapat dikatakan bahwa hipotesis alternatif dapat diterima. Artinya kesimpulan dalam penelitian ini adalah kepercayaan memiliki pengaruh positif dan signifikan terhadap keputusan pembelian.

Nilai signifikansi untuk variabel keamanan adalah sebesar $0,001<0,05$ yang didukung oleh nilai $\mathrm{t}$ hitung sebesar 3,292 > t tabel sebesar 1,983 maka dapat dikatakan bahwa hipotesis alternatif dapat diterima. Artinya kesimpulan dalam penelitian ini adalah keamanan memiliki pengaruh positif dan signifikan terhadap keputusan pembelian.

Nilai signifikansi untuk variabel kualitas pelayanan adalah sebesar $0,033<0,05$ yang didukung oleh nilai t hitung sebesar 2,160 > t tabel sebesar 1,983 maka dapat dikatakan bahwa hipotesis alternatif dapat diterima. Artinya kesimpulan dalam penelitian ini adalah kualitas pelayanan memiliki pengaruh negatif dan signifikan terhadap keputusan pembelian.

Nilai signifikansi untuk variabel kualitas produk adalah sebesar 0,008 $<0,05$ yang didukung oleh nilai $t$ hitung sebesar 2,713 > t tabel sebesar 1,983 maka dapat dikatakan bahwa hipotesis alternatif dapat diterima. Artinya kesimpulan dalam penelitian ini adalah kualitas produk memiliki pengaruh positif dan signifikan terhadap keputusan pembelian.

Nilai signifikansi untuk variabel persepsi resiko adalah sebesar 0,002 $<0,05$ yang didukung oleh nilai t hitung sebesar 3,116 > t tabel sebesar 1,983 maka dapat dikatakan bahwa hipotesis alternatif dapat diterima. Artinya kesimpulan dalam penelitian ini adalah persepsi resiko memiliki pengaruh positif dan signifikan terhadap keputusan pembelian.

\section{Uji f Simultan}

Hasil uji f simultan dalam penelitian ini adalah :

Tabel 5. Hasil Uji f Simultan ANOVA $^{\mathrm{a}}$

\begin{tabular}{|ll|r|r|r|r|r|}
\hline \multicolumn{2}{|l|}{} & \multicolumn{1}{|c|}{ Sum of } & & & & \\
\hline 1 & Squares & df & Mean Square & F & Sig. \\
\hline & Regression & 1770.049 & 5 & 354.010 & 141.634 & $.000^{\mathrm{b}}$ \\
& Residual & 234.951 & 94 & 2.499 & & \\
& Total & 2005.000 & 99 & & & \\
\hline
\end{tabular}

a. Dependent Variable: Keputusan Pembelian

b. Predictors: (Constant), Persepsi Resiko, Kualitas Pelayanan , Kepercayaan,

Keamanan , Kualitas Produk

Sumber : Hasil Pengolahan, 2019 
Berdasarkan tabel 5 di atas dapat dijelaskan bahwa nilai signifikansi untuk uji $\mathrm{F}$ simultan adalah sebesar $0,000<0,05$ yang didukung oleh nilai $\mathrm{F}$ hitung sebesar 141,634 > F tabel sebesar 2,305 maka dapat dikatakan bahwa hipotesis alternatif dapat diterima. Artinya kesimpulan dalam penelitian ini adalah variabel kepercayaan, keamanan, kualitas pelayanan, kualitas produk, dan persepsi resiko memiliki pengaruh secara bersama-sama atau simultan terhadap keputusan pembelian.

\section{Uji Koefisien Determinan}

Hasil uji koefisien determinan pada penelitian ini adalah :

Tabel 6. Hasil Koefisien Determinan Model Summary ${ }^{\mathbf{b}}$

\begin{tabular}{|l|r|r|r|r|}
\hline Model & R & R Square & \multicolumn{1}{c|}{$\begin{array}{c}\text { Adjusted R } \\
\text { Square }\end{array}$} & $\begin{array}{c}\text { Std. Error of } \\
\text { the Estimate }\end{array}$ \\
\hline 1 & $.940^{\mathrm{a}}$ & .883 & .877 & 1.58097 \\
\hline
\end{tabular}

a. Predictors: (Constant), Persepsi Resiko , Kualitas Pelayanan ,

Kepercayaan, Keamanan , Kualitas Produk

b. Dependent Variable: Keputusan Pembelian

Sumber : Hasil Pengolahan, 2019

Berdasarkan tabel 6 di atas dapat dijelaskan bahwa nilai adjusted $R$ square yang terbentuk adalah sebesar 0,877 . Artinya kemampuan variabel independen dalam hal ini adalah kepercayaan, keamanan, kualitas pelayanan, kualitas produk, dan persepsi resiko terhadap variabel dependennya dalam hal ini adalah keputusan pembelian sebesar $87,7 \%$ sedangkan sisanya sebesar $12,3 \%$ dipengaruhi oleh variabel lain selain dari variabel yang tidak dimasukkan ke dalam model penelitian.

\section{KESIMPULAN}

Berdasarkan serangkaian hasil uji statistik yang telah dilakukan maka kesimpulan dalam penelitian ini adalah :

1. Berdasarkan uji t parsial dapat disimpulkan bahwa kepercayaan memiliki pengaruh positif dan signifikan terhadap keputusan pembelian karena nilai signifikansi yang diperoleh sebesar $0,000<0,05$ yang didukung oleh nilai $t$ hitung sebesar 4,589 $>\mathrm{t}$ tabel sebesar 1,983 .

2. Berdasarkan uji t parsial dapat disimpulkan bahwa keamanan memiliki pengaruh positif dan signifikan terhadap keputusan pembelian karena nilai signifikansi yang diperoleh sebesar 0,001<0,05 yang didukung oleh nilai thitung sebesar 3,292 >t tabel sebesar 1,983 .

3. Berdasarkan uji t parsial dapat disimpulkan bahwa kualitas pelayanan memiliki pengaruh negatif dan signifikan terhadap keputusan pembelian karena nilai signifikansi yang diperoleh sebesar 0,033 $<0,05$ yang didukung oleh nilai $\mathrm{t}$ hitung sebesar 2,160 $>\mathrm{t}$ tabel sebesar 1,983.

4. Berdasarkan uji t parsial dapat disimpulkan bahwa kualitas produk memiliki pengaruh positif dan signifikan terhadap keputusan pembelian karena nilai signifikansi yang diperoleh sebesar $0,008<0,05$ yang didukung oleh nilai $t$ hitung sebesar 2,713 $>\mathrm{t}$ tabel sebesar 1,983 .

5. Berdasarkan uji t parsial dapat disimpulkan bahwa persepsi resiko memiliki pengaruh positif dan signifikan terhadap keputusan pembelian karena nilai signifikansi yang diperoleh sebesar $0,002<0,05$ yang didukung oleh nilai $t$ hitung sebesar 3,116 $>\mathrm{t}$ tabel sebesar 1,983 .

6. Berdasarkan uji F simultan dapat disimpulkan bahwa kepercayaan, keamanan, kualitas pelayanan, kualitas produk, dan persepsi resiko memiliki pengaruh secara bersama- 
sama terhadap keputusan pembelian karena nilai signifikansi yang diperoleh sebesar $0,000<0,05$ yang didukung oleh nilai $\mathrm{F}$ hitung sebesar 141,634 > F tabel sebesar 2,305.

\section{E. DAFTAR PUSTAKA}

Firdayanti, Restika. (2012). Persepsi Risiko Melakukan E-Commerce Dengan Kepercayaan Konsumen Dalam Membeli Produk Fashion. Journal of Social and Industrial Psychology. FP-UNNES. Halaman 1-7.

Hariyanti, Maulina. (2012). Kepercayaan Pada Penjual dan Persepsi Risiko Pada Keputusan Pembelian Melalui Internet (Online). Skripsi. Yogyakart: Universitas Islam Negeri Sunan Kalijaga.

Kotler, Philip dan Gary Amstrong. (2012). Marketing Management. 14th Edition New Jersey: Pearson Pretice Hall, Inc.

Kotler, Philip dan Gary Amstrong. (2016). Prinsip-Prinsip Pemasaran. Edisi 13. Jilid I. Jakarta: Erlangga.

Masoud, E, Y. (2013). The Effect of Perceived Risk on Online Shopping in Jordan.

Rosalia, D.dan Ellyawati, J. (2016). Pengaruh Persepsi Risiko Terhadap Kepercayaan dan Keputusan Pembelian Online.

Sugiyono. (2016). Metode Penelitian Kuantitatif, Kualitatif dan R\&D. Bandung: PT Alfabeta.

Sukma, Abdurrahman Adi. (2012). Analisis Faktor-Faktor Yang Mempengaruhi Keputusan Pembelian Social Networking Websites. Jurnal Ekonomi Manajemen, Fakultas Ekonomi Universitas Gunadarma.

The Nielsen Global Survey Of E-Commerce. (2014). Kebiasaan Belanja Online.

Tjiptono, Fandy. (2012). Service Management Mewujudkan Layanan Prima. Yogyakarta: CV Andi Offset.

Tjiptono, Fandy. (2016). Service, Quality \& Satisfaction. Yogyakarta, Andi.

Wijaya, Megawati dan Farida Jasfar. (2014). Pengaruh Rancangan Situs, Harga, Kepercayaan dan Keamanan Terhadap Pembelian Produk Fashion Melalui Online Shopping. Jurnal Manajemen dan Pemasaran Jasa. Volume 7. Nomor 2. Halaman 31-62.

Yovirizka, Inggarani U. \& Wahjoedi. (2018). Trend Keputusan Belanja Online Mahasiswa Fakultas Ekonomi UM Angkatan 2014. Jurnal Ekonomi. Vol.11. No.1. 